\title{
文京区駒込の町地の成立と変遷 \\ ESTABLISHMENT AND TRANSFORMATION OF TOWNSPEOPLE'S LAND IN KOMAGOME DISTRICT, BUNKYO
}

\author{
渡 邊 美 樹* \\ Miki WATANABE
}

\begin{abstract}
This study employs historical maps and data to examine the establishment and transformation of the townspeople's land Cyonin-chi in Komagome district. Few townspeople's areas appeared before the Edo Period. In the early Edo Period, some farmlands were requisitioned as infantry residential land (Kumi-yashiki) or other feudal government land. Furthermore, many temples were relocated along with commercial towns (Monzen) in the Edo Period. Eventually, the townspeople's land in this area began to expand.
\end{abstract}

Many townspeople's lands were authorized as Machi-kata in 1737 and controlled by a town magistrate (Machi-Bugyo) in 1745. This analysis found that the townspeople's lands in this area were organized into five categories as follows:

I . Hairyo-machi-ya: Bestowed townspeople's land

II . Townspeople's land of Rinsyo-in's territory

III . Townspeople's land of Dentu-in's territory

IV . Hyakusyo-machi-ya: Townspeople's land inclusive of other temple's territory

V . Monzen: Commercial town in front of temple

Keywords: Komagome, Machikata-Kakiage, Townspeople's area,Buddhist temple territory, Monzen, Transformation 駒込, 町方書上, 町人地, 寺院領地, 門前, 変容

\section{1. はじめに}

筆者はこれまでに、台東区谷中、西浅草および文京区駒込地区を 対象として、18 世紀前半までに寺町が形成された経緯を把握した 上で、明治初期の寺領上地から現在までの寺地の領域と用途の変化 を検証し、江戸外縁部の寺地の形成と変容についての検討を行った 1)，2，3）。台東区谷中地区においては、江戸期に他宗派寺院から境内 地を借地していた寺院が多数あったこと、上地後下戻しの際には借 地にはかえって優遇処置がとられ、寺地を所有する例が多かった事 などを述べた。西浅草地区においては、震災後の区画整理によって 寺地が分断された上、道路沿いは宅地としての運用がなされており、 境内地が街区の中心部に残存している状況であることを確認した。 駒込地区では寺領上地の際、境内が江戸期の捧領地の約半分となっ たこと、境内民有地と認められた寺地は江戸期の年貢地や自費開墾 の労を訴えた土地であったことを述べた。またこの稿において、江 戸期の境内、町人地、農地の多くが麟祥院と伝通院の寺領であるこ とを確認したことから、さらに谷中、駒込、小石川地区に存在した 寛永寺、麟祥院、伝通院の寺領町人地について報告した ${ }^{4)}$ 。安政 3 （1856）年重ね地図によると、このように寺院の境内から離れた箇所 に数力所以上の寺領町人地を持つ寺院は、これら 3 寺院の他に増上 寺 (主に巣鴨)、浅草寺（主に浅草）、護国寺（主に大塚、音羽）が
認められる。さらにこれら 6 寺院のなかでも麟祥院は、境内近隣に まとまった子院や門前を伴わず離れた箇所に寺領町人地を形成して いるという、他の寺院にはない特徴がみられる。本来、寺領町屋は 門前という形式をとり、寺院に付随して寺院への参拝者からの収入 を期待する商業区域と認識されるが、寺院境内から遠く離れた箇所 に寺領町地が構えられて経済的な繫がりを持つとは、果たしてどの ような経緯によるものなのだろうか。めまぐるしく改変し続ける都 市空間の中で、寺地や墓地は江戸期から元の地点を保っている数少 ない場所といえ、また将来も維持され得る貴重なスペースである。 一方町地は、武家や寺院あるいは町人同士の物資の需要に応じる店 舗、街道の市場や宿場と共に町人達の居住スペースとして成立し、 明治以後は武家地や農地を取り込みつつ「宅地」として拡張し続け てきた。

そこで本研究においては、筆者がこれまでに行ってきた江戸期の 寺町の形成と明治以降の寺地の変遷についての研究をふまえて、江 戸期の寺領農地の町化を検証すると共に、本地区の町地の成立過程 と公課の違いから町地の種別を整理しつつ、町の視点から、江戸外 縁部の市街化の過程と土地利用の多様性について考証する事、また 明治以降の土地利用の変化について縦断的に検討し、江戸期の種別 との関連性について若干の考察を加える事を目的とする。 
江戸の町地の成立や変遷については、すでに数多くの調査結果や 研究報告があり、本研究はそれらの先行研究を参照としている。ま ず農村地からの町並地の発生について岩淵令治氏は、耕地が武家地 などの運用をなされた時点以降の敷地を「地所」と呼び、駒込村を 対象として町地の成立時期を明らかにし、御用地および武家屋敷の 各地所における実際の利用状況と経済状況、町屋敷の買得や運用、 町の居住者の生業と町役についてとりあげ、駒込が典型的な場末の 町並地であったこと、近郊農家からの物資の集荷点であり、武家屋 敷への小売り商としても機能していたなど、武家地と町人地との経 済的関係性を述べている ${ }^{5)}$ 。また吉原健一郎氏は、江戸期の土地を めぐる状況の背景として、寛永 20（1643）年に田畑永代売買禁止令 が出たにもかかわらず武士が農地や町地を購入していた事などを取 り上げて、土地の身分別ゾーニングは早期に摇らいでおり、「武士は 武家地」ということが崩壊していた事実を述べている ${ }^{6)}$ 。

一方、江戸の町や町屋敷については、絵図や書上などの史料から 町屋敷の状況を詳細に復元する研究が数多くなされており、「江戸住 宅事情」もその成果の一つである。本書では日本橋、神田など江戸 中心部と下谷、四谷など外縁部の町地の町絵図や屋敷図によって地 代店賃、町入用などを検討し、江戸の町地の経済事情と居住環境を 明らかにしている ${ }^{7)}$ 。また吉田伸之氏は、近世以降の町絵図、沽券帳、 人別帳などの史料をもとに、町人地の住人や生業の構成について検 討し、仲間や組織としての町の仕組み、秩序と空間構造について詳 細な考証をおこなっている ${ }^{8)}$ 。さらに藤川昌樹氏は、大名が町屋敷 を買得し藩士や家臣の寄宿・滞在先を確保していた経緯を明らかに する事によって、近世以降既に武家集団の居住地（武家地）は町人 地に侵入する状況であったことを述べている。つまり、町人地の一 部が実際には武家地の用途をなしており、絵図にみられる明確な彩 色による身分制の領域分けとは異なる土地利用がなされていたこと 示唆している ${ }^{9)}$ 。

明治以降の大名屋敷地の宅地化について松山恵氏は、江戸の「場 末の町々」が中心部の武家地へと移転し、新開地を形成した計画が、 町人の経済的基盤や納税の程度によって住人を配置し直す政府の意 向、つまり住居形態や貧富を判断基準として武家地一の町人（貧民） の乱入を防ぎっつ武家地の宅地化を計ったことと、中心部へ移転を 望む町人の意向とが合意した結果であったとして、明治初期からの 旧武家地の「新開地計画」について述べている ${ }^{10)}$ 。また加藤仁美氏は、 麻布霞町の旧棚倉藩阿部家播磨守下屋敷の敷地を対象として、基盤 の整備や区画整備、土地の賃貸や管理委任を含め、昭和 35 年までの 所有関係と宅地化の経緯を明らかにしている ${ }^{11)}$ 。これらの先行研究 により江戸期の町人地の状況を振り返ると、「場末」といわれる町地 で財をなした町人、中心部からの替地によって「場末」の町地へ移 動せざるをえなかった町人、あるいは農民から商売を興し財をなし た町人など、江戸末期の「場末」の町地はもはや均質な町人・商人 の居住地ではなく、貧富の格差が高く経済状況が異なる人々がせめ ぎ合う居住地区であったことがわかる。

本稿で対象とする駒込地区の町地は、文政 9 (1826) 年町方書上の 「駒込壱から四」に記載されている町とする（表 1、図 1)。この地区は、 日光御成道と中山道といった主要街道沿いに位置しており、人や物 資が常に流れ、地方との交流拠点ともなっていることから、町が変 化し発達し続ける要因をもっている。また本地区周縁には、広大な
麟祥院領百姓地がひろがる一方で、福山藩 (阿部家) や加賀藩 (松平家) 江戸藩などの広大な武家地（藩邸）と寺地が相互に存在しているこ とから、江戸期の土地利用について、また明治期への移り変わりに ついても様々な様相を読み取る事ができる。

\section{2. 江戸期の町地形成と支配}

\section{2-（1）江戸期までの概要}

江戸後期までの当地区の様子は、文政 11 （1828）年完成の新編武 蔵風土記稿 ${ }^{12)}$ から知ることができる。豊島郡之十一岩淵領上駒込 村および下駒込村に関する記述を要約すると、以下の事柄が抽出さ れる。

【上駒込村】日本橋の北一里二十町

- 小田原役帳に知行 36 貫文江戸駒込と記す、正保の改に駒込村御料 所の他伝通院領注 1) および天澤寺領注 ${ }^{2 ）}$ と載す。

・村の上と下の境界は曖昧で決めがたく、東は中里田端新堀、谷中、 西は町方、北は巣鴨西ヶ原を境界とし、東西 20 町、南北 11 町、家 敷 107 件あり。

・薄土のため穀物には適さず、茄子、庭樹盆栽を産業とする。

・寬永 $10 （ 1633 ）$ 年検地が行われた。寛文 5（1665）年に御料所の多 くは伝通院領となり、残りは駒込片町名主八左衛門が預かり、今藤 堂大学の抱添地となる。

・宝永 3 （1706）年榊原式部大輔が下屋敷に賜った土地の替地が板橋 村にあり。この地は享保 2（1717）年上地となり翌年御鷹匠同心居 地となる。

・ 上下駒込村のうち町方に属するのは片町、三ツ家町、肴町、四軒寺 町、富士前町、上富士前町、七軒町、三軒家町、妙義坂町、千駄木 町、千駄木坂下町、千駄木下町などで冠に「駒込」がつく。そのう ち片町と号するのは 2 䇢所、南にある方は元御料所で古くから村民 の商店があり、正徳 3 （1713）年に町奉行に属した。

・片町以下 11 ケ町が伝通院あるいは麟祥院領である。元文 2 (1737) 年に百姓町となり、延享 2 (1745) 年町奉行支配に属する。その他 駒込追分町、九軒屋敷、浅嘉町なども元村内の地だが、元和から天 和年中（1615-1684）までに追々武家扯領町屋敷となり村高を除か れた。

【下駒込村附千駄木御林跡地】日本橋より一里十町

・家屋敷は 110 軒あり植木屋が多い。

•正保 4 (1647) 年湯島麟祥院 (天澤寺) 領となる。検地は宝永 4 (1707) 年に行われた。

\section{【舊家者】}

・今井五郎兵衛 文明年中（1469-86）から当地一住み、村を開いた。 200 年前から今井民部と称する。文化 2（1805）年苗字を名乗るこ とを免された。

・五平治 先祖を高木将監といい、慶長（1596-1615）の頃村を開いた。 さらに麟祥院領については、寛永 11（1634）年に柏木村 100 石、 寛永 $20 （ 1643 ）$ 年に春日局の永代供養料として駒込村の内 200 石を 賜ったが、駒込村の領地は幾度となく武家屋敷、寺地や町屋敷とし て上地されて水帳も無いままであったので宝永 3 （1706）年に検地を 願い出たところ、宝永 4（1707）年に実施された。また検地の結果、 合計 300 石賜った寺領は 624 石余りとなり、麟祥院領になってから 百姓他の労によって石高が格段にあがっていたと記録されている ${ }^{13)}$ 。 
表 1 駒込町方書上および小間附年間による町の成立経緯と類型

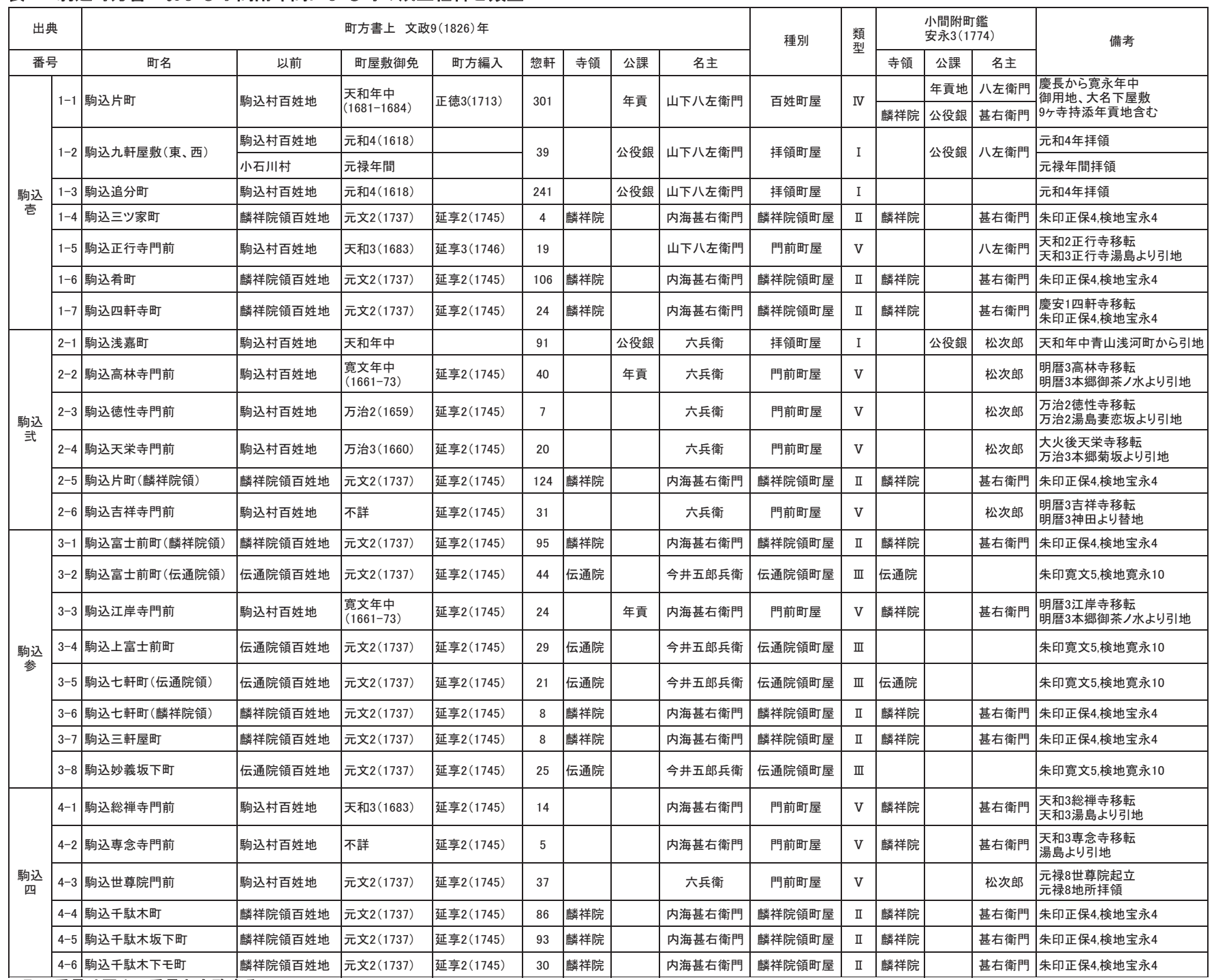

\section{*町の番号は图 1 の番号と合致する。}

また後の天保年中（1830～44）の村高は合計 410 石とある ${ }^{14) 。 こ ~}$ の様に当地区は、17 世紀初等までに複数の農民が村を開いた後、多 くは麟祥院と伝通院の領地となった。その後も御用地（御鷹匠、同 心屋敷など）や武家屋敷への公收がたびたびあったが、江戸末期ま で農地が残っていたことが解る。

\section{2-（2）諸資料による江戸期における町の成立}

ここでは、文政 9（1826）年町方書上および諸資料 13）～16）の記 述から、この地区に町が成立した具体的な経緯をみる。まず、町方 書上に示されている町は、「駒込壱」が 7、「駒込武」が 6、「駒込参」 が 8、「駒込四」が 6 の計 27、牢数は計 1566 軒である。これらの町 地について、町地になる以前の状況と検地・替地の年代、町屋敷御 免および町方支配の年代、名主を抽出し、さらに安永 3 (1774) 年 小間附北方町鑑による寺領と公課とを表にまとめたものが表 1、こ れらの町域および周辺の状況を安政 3 (1856) 年重ね地図*1にプロッ トしたものが図 1 である。

図 1 をみると、まず「駒込壱」と「武」は日光御成道と谷中通り の交差点（2-1 駒込淺嘉町）を境として南北に分かれる。「参」はお おむね日光御成道の吉祥寺以北にあり、「四」は谷中通り（団子坂） 沿いの東側（坂中から坂下）に位置する。まず町地となる以前に麟
祥院領百姓地であった町は、1-4 駒込三ツ家町、1-6 駒込肴町、1-7 駒込四軒寺町など 10 ケ町ある。これらはいずれも宝永 4（1707）年 に検地、元文 2（1737）年に町屋敷御免、延享 2（1745）年に町方支 配（町方編入）がなされており、麟祥院領である（II）。一方、以前 に伝通院百姓地であった町は、3-2 駒込富士前町、3-4 駒込上富士前 町、3-5 駒込七軒町、3-8 駒込妙義坂の 4 ケ町であり、いずれも寛永 10（1633）年に検地、元文 2（1737）年に町屋敷御免、延享 2（1745） 年に町方支配で「伝通院領四ヶ町」と記載されている（III）。次に、 1-1 駒込片町は駒込百姓地から御用地を経て町地となったとあり、 付近 9 ケ寺の持添年貢地注 ${ }^{3)}$ を含む百姓町屋である (IV)。さらに 駒込村・小石川村百姓地から元和、元禄年間に町屋敷となったのが 1-2 駒込九軒屋敷、1-3 駒込追分町であり、町地の引地が 2-1 駒込淺 嘉町で择領町屋は合計 3 ケ町ある（ I ）。天和 3 （1683）年湯島から 寺院の移転により門前町屋が引地された例は 1-5、4-1、4-2 の 3 ケ 町、明暦大火後に本郷、湯島、神田およびお茶の水から寺院の移転 による門前町屋の引地が、2-2、2-3、2-4、2-6、3-3 の 5 ケ町、さ らにその地に起立した寺院の門前町屋が 4-3 世尊院門前であり門前 町屋は計 9 ケ町ある $(\mathrm{V})$ 。このうち 3-3 江岸寺門前、4-1 総禅寺門前、 4-2 専念寺門前の 3 ケ町は、町以前は駒込百姓地であるにも関わらず、 


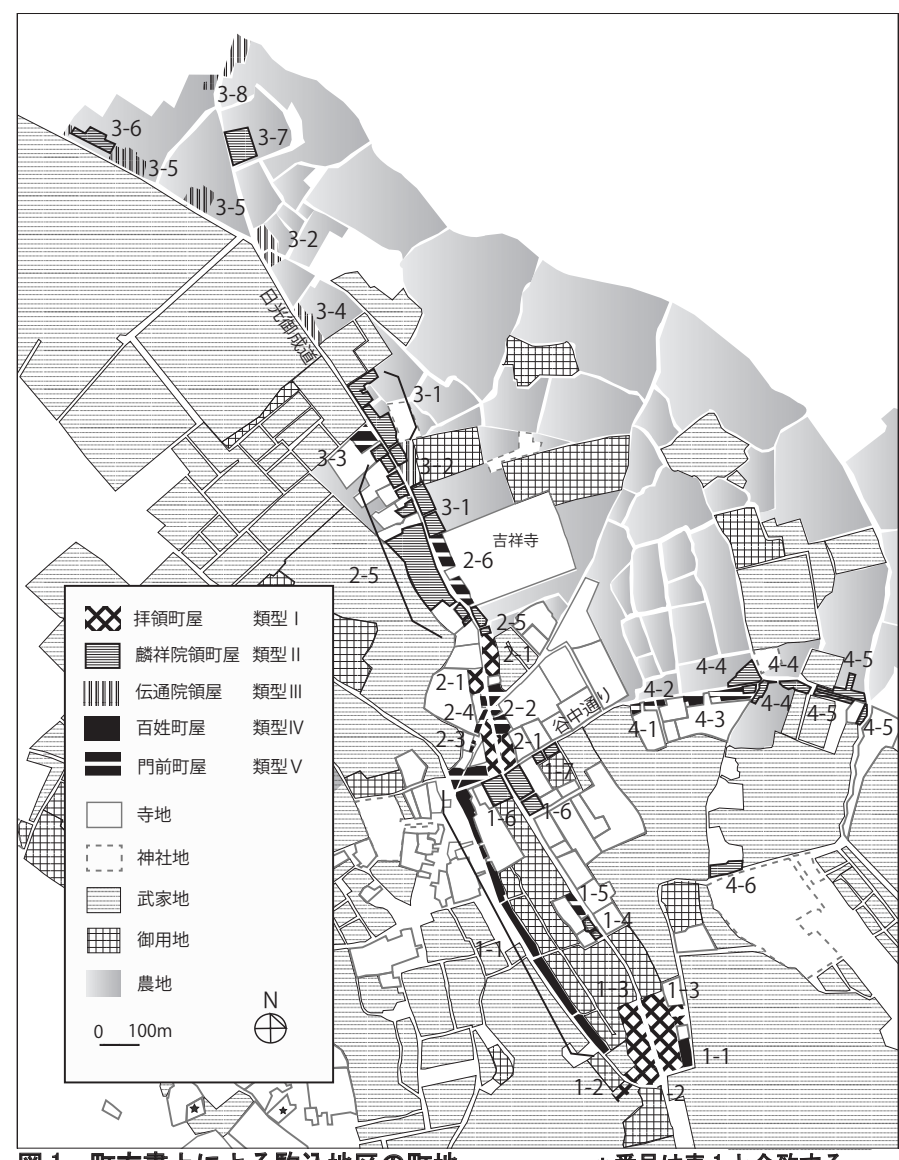

図 1 町方書上による駒込地区の町地

小間附町鑑に「麟祥院領」と記載されている。

以上、本地区の町地の種別は以下の 5 つに整理できる。

I . 拝領町屋 (3 町 371 軒)

II . 麟祥院領町屋 (10 町 578 軒)

III. 伝通院領町屋（4 町 119 軒）

IV. 百姓町屋（1 町 301 軒）

V. 門前町屋（9 町 197 軒）

次に名主の割り当てをみると、II の 10 ケ町と小間附町鑑で麟祥 院領と記載されている門前町屋 3 ケ町を内海甚右衛門注 4$)$ が支配し、 III の伝通院領 4 ケ町を今井五郎兵衛が支配している。このように、 麟祥院領と伝通院領については明確に 2 名に分かれる。I 扯領町屋、 $\mathrm{IV}$ 百姓町屋および $\mathrm{V}$ 門前町屋（麟祥院領以外）については、「駒込 壱」内が山下八兵衛、「武」と「四」が六兵衛である。公課について は麟祥院、伝通院領町屋およびIVの百姓町屋については年貢である。 町方書上には、拝領町屋に「公役金」と記載されているのみで、門 前町屋については 2-2 高林寺門前と 3-3 江岸寺門前以外の記載はな いが、おおむ稏貢を納めていたものと推測できる。以上のように、 町地の種別、領主と支配領域には深い関わりがあることが明らかと なった。ちなみに麟祥院文書によると、内海甚右衛門と今井五郎兵 衛は駒込村の村方名主を兼任している。

2-（3）江戸期の駒込村名主 : 内海と年寄 : 高木についての「安政年 代駒込周辺之図」の記述と大正元年地籍図による所有地

前項でも検討したとおり、内海（甚右衛門）は駒込の麟祥院領町方 と駒込村の名主を勤めた。一方、前述した駒込村の「舊家者 高木将監」 の子孫で駒込村の村役として麟祥院文書にもしばしば登場するのが高

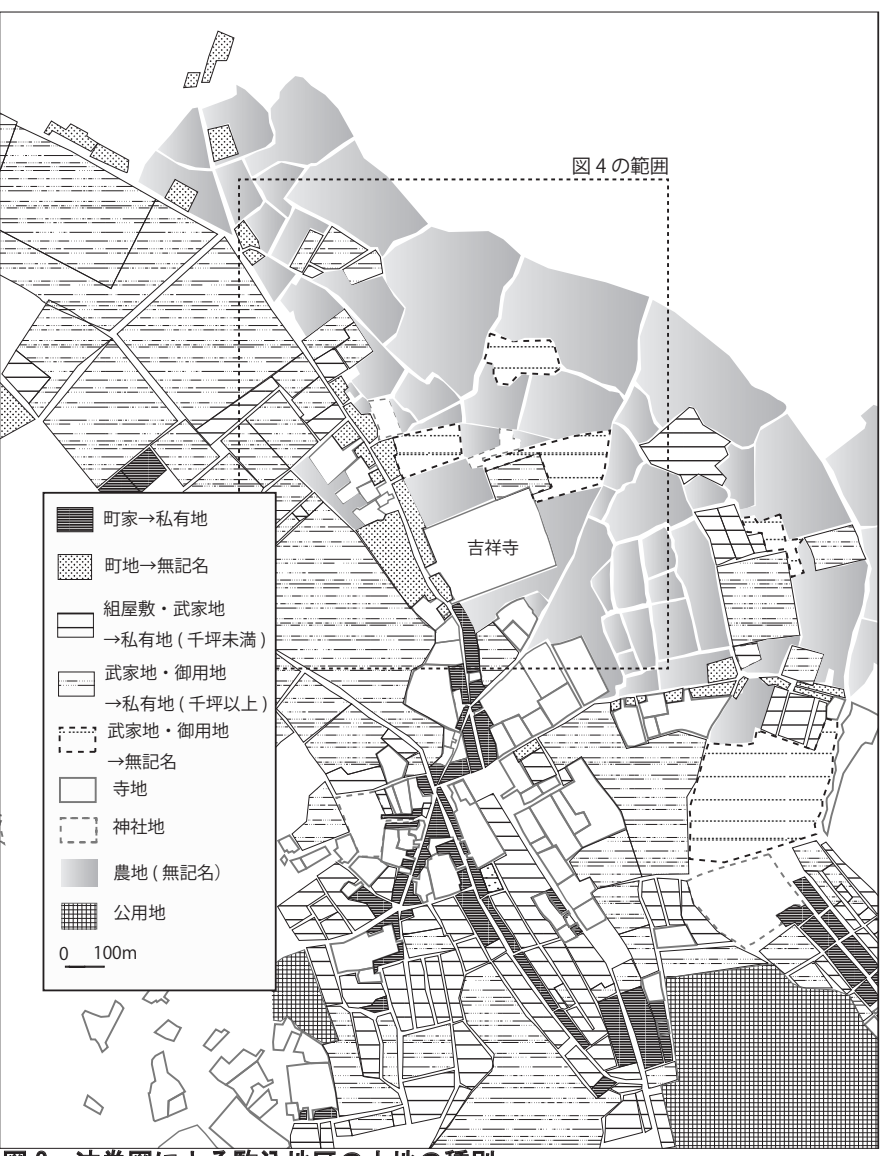

\section{图2 洁券図による駧込地区の土地の種別}

木嘉平次（嘉平治）である注5)。高木の住居は、東京都史跡「駒込名主 屋敷」として現存しており、都内では数少ない江戸時代の村役宅住居 の遺構となっている ${ }^{17)}$ 。ここでは、「安政年代駒込周辺之図」および 大正元年地籍地図・台帳 ${ }^{2}$ による内海、高木両家に関する記載を比較 検討し、さらに明治以後の農地と町地の所有について考察する。

図に記載されている説明文によれば、「安政年代駒込周辺之図（その 一)〜 (その三)」(図 3 に一部を掲載）は、富士前町（現本駒込町） 海老床の主人: 嶋村八十八が明治 43 年頃から、作者の父が子供の頃（作 者が安政年間と判断）の記憶を語る事柄を書き留めたものであり、大 正 5 年までに下書きを描いて昭和 10 年に完成した記録を、昭和 56 年 に新宿区の萩野氏が入念に書き写したものである。図に記載されてい る町名主（今井）は諸資料と一致し、高木嘉平次の居宅の位置は現在 の「駒込名主屋敷」の位置と合致する点などから、後世に作成された 記録とはいえ、かなり信憑性のある資料といえる。この図は現在、文 京区ふるさと歴史館に保管されている。まず、麟祥院領町屋および駒 込村の名主であった内海については、一箇所に「農卜植木中 源之亟 (内海)」という記載がある。さらに「高木」についての記載を抽出し、 周辺の寺院や街道との位置関係を参照して重ね地図にプロットしたも のが図 4 である。さらに、大正元年地籍台帳により、内海源之亟、内 海長太郎と高木嘉平次の子孫である信吉、高木捨次郎、菊太郎、元太 郎の所有地を抽出し（表 2）、地籍図の領域をプロットしたものが図 4 である。すなわちこの図には、安政年代の内海、高木の住居や店と大 正元年の所有地の情報が重なっている。まず、内海源之亟（甚右衛門） と高木信吉（嘉平次）の住居の位置には変化がない。内海は名主、高 木はこの地の村年寄だった記録が残されていることから、両者は江戸 
期に駒込村の地主の中でも最上位の家系であったと考えられる。地租 改正の後、明治期を経て土地の売却などがなされた結果、大正元年の 地籍地図にみる領域が残ったと考えられ、この領域は江戸期の両家の 所有地の一部であったといえる。大正元年当時、高木は駒込富士前町 の街道沿いの敷地を所有しており、江戸期の町方では 3-1 駒込富士前 町 (麟祥院領) にあたる。「駒込周辺之図」では「よろずや○兵衛 (高木)」 とあり、江戸期から店を構えて商売をしていた事がわかる。これにより、 古くからの農民が、街道沿いの土地の町化によって江戸期に店を構え て町人化する過程をよみとる事ができる。

\section{3. 明治初期の変化}

3-（1）沽券図による土地の種別

前項でみたように、江戸期の駒込地区の町地は寺領の割合が圧倒的 に多い。一方で安政 3（1856）年の町地の周辺を見ると（図 1)、北東 部に広大な農地が広がる反面、北西部と南部には武家屋敷と御用地が それぞれ広大な領域を占める。明治初期の寺社地および武家地上地に よって、これらの土地の所有 (土地利用) はどのような構成へと変化 したのだろうか。

前稿 ${ }^{3)}$ でも示したとおり、寺領の処分は明治 3（1870）年に概要調 查が始まり、明治 4 年正月上知令、寺地境内外区別と建物調查、明治 8 年現地調查と境内外境の告示、明治 10 年に記録の提出要請と提出、明 治 11 年境内外の決定、明治 12 年以後に境内官有地払下げなどの処分 という経過がある。その間の土地関連の動きをみると、明治 2 年沽券 状改正、明治 4 年 7 月廃藩置県で御用地・武家地上地がこれにあたり、 同年 8 月朱引外区改正、明治 5 年 2 月地券発行、明治 6 年地租改正と いう手順で進められている。すなわち、明治 6 年作成された沽券図 ${ }^{* 3}$ は、 沽券状改正と地券発行後の記録であるため、これにより寺社地武家地 上地後の地目 (名義) を知る事ができる注 6)。沽券図に記されている 地目を同スケールでプロットしたものが図 2 である。図 1 と 2 を比較 検討すると、まず 2-5、3-1、3-6、3-7、4-4 など麟祥院領町地のほと んどが無記名（名義なし）であることが解る。同じく $3-2 、 3-4 、 3-5 、$ 3-8の「伝通院領四ヶ町」も無記名である。さらに 3-3、4-1、4-2の 門前町屋で小間附町鑑で麟祥院領と記載されている箇所もすべて無記 名である。周辺の村地をみると、「農地」という表記はあるものの地券 者名は記入されていないことから、これらの町地は元の地主（百姓） への返却や居住者への譲渡の過程にあったと推測される。一方、1-2、 1-3、2-1の拝領町屋および 1-1 の百姓町屋と 2-2、2-4の門前は私有地 となっている。また、千坪以上の広大な武家地では、江戸末の所有者 名が継続して記載されている例が多いが、江戸期に既に敷地が小分割 されていた武家地や御用地は、ほとんどの敷地で所有者の名前が変わっ ていることを確認した注7)。

以上、江戸期の町地の領主は明治初期における沽券の名義と深く関 わっており、本地区では特に徳川家菩提寺の寺領町地が多かったこと により、その特徵が顕著に表れていることが解る。

\section{3-（2）地籍図による土地の種別}

本地区付近の武家地、町地の払下げについては明治 7、8 年の記録が ある。明治 8 年には府下の屋敷地百坪以下の分割売買が解除となり、 また耕地・宅地・山林など全ての土地の売買が自由となった ${ }^{14)}$ 。その 後は、明治期に各地所や農地が次々と宅地化・市街化されたことは言 及寸るまでもない。ここでは明治期の土地売買・運用の結果として、

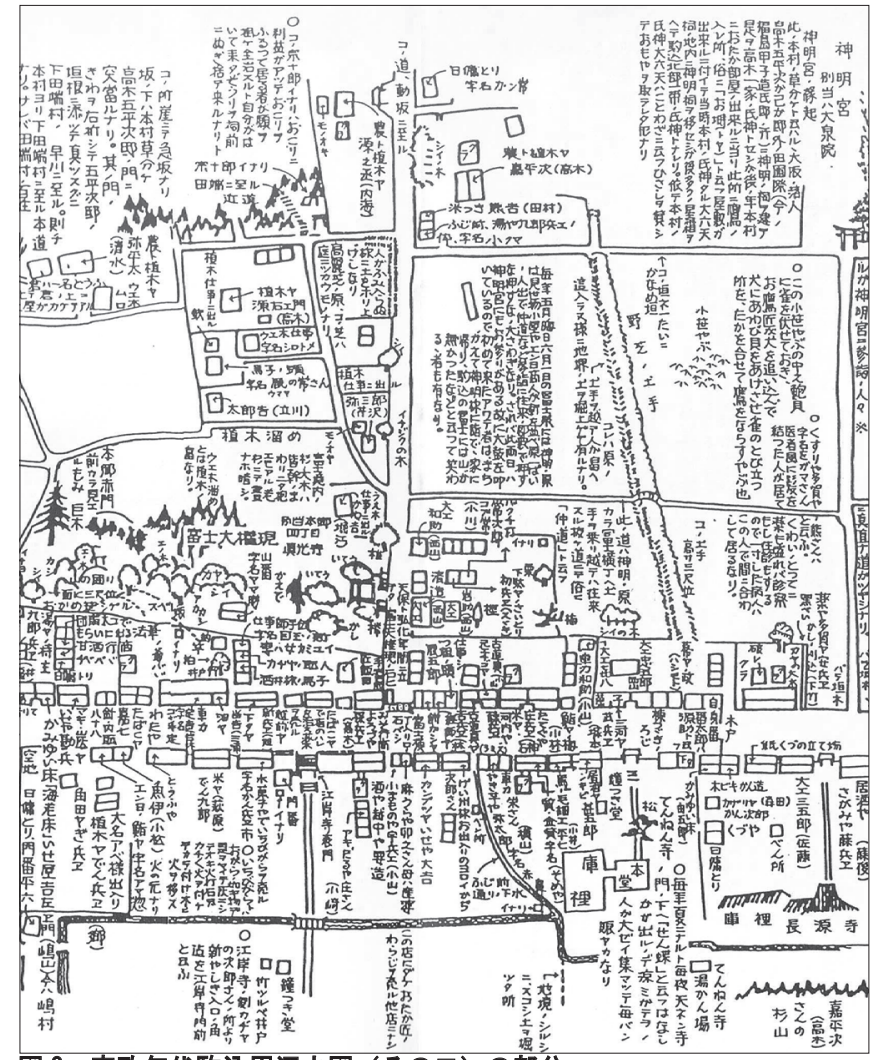

\section{図 3 安政年代駒込周辺之図（その二）の部分}

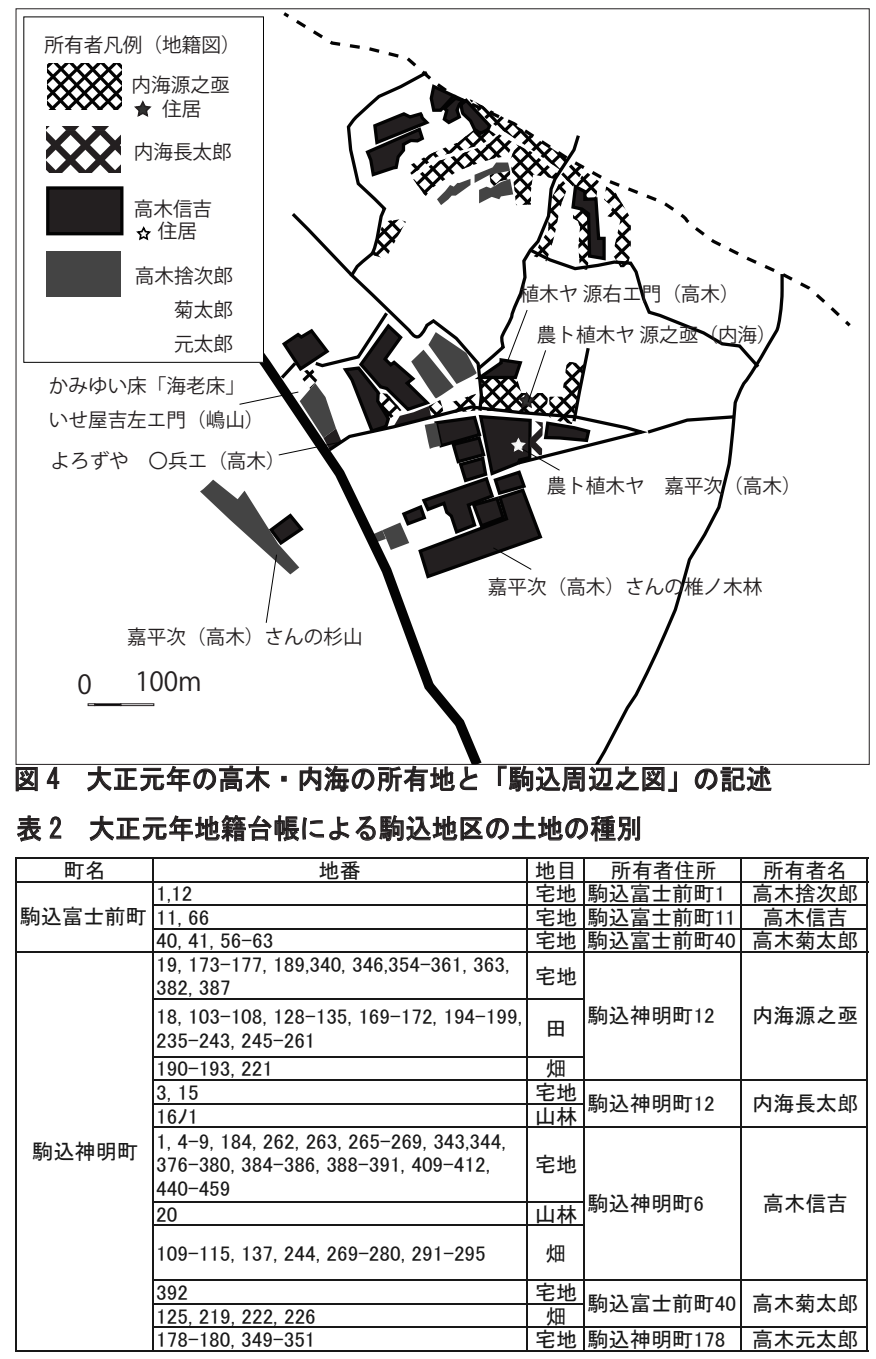




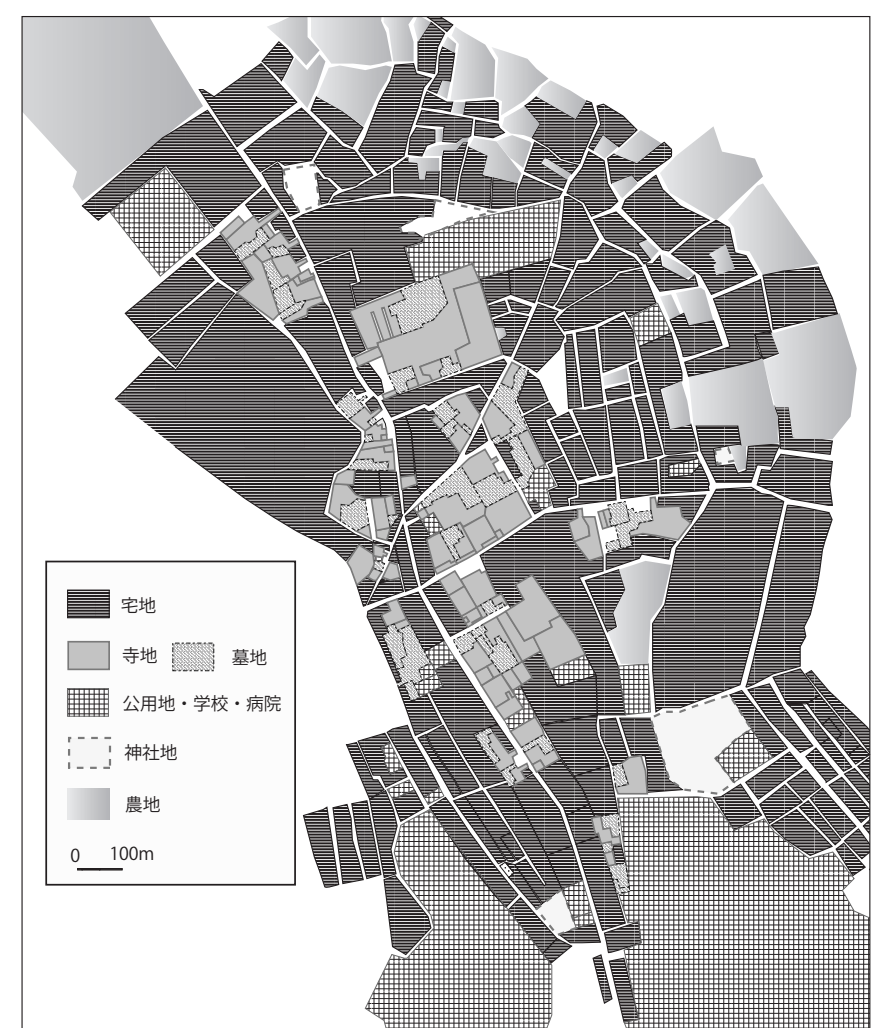

図 5 大正元年地籍図・地籍台帳による駒込地区の土地の種別

大正元年地籍図・台帳を参照し、私有地（宅地）の拡張をみる（図 5)。 まず、江戸期の町地で沽券図では無記名であった箇所は、全て宅地 となっている。これは、寺領が上地された後に元の地主（百姓）への 返却と当時の居住者への譲渡などがなされた結果である。江戸期の武 家地・御用地などで沽券図では無記名だった箇所は、公立病院（都立 駒込病院）の敷地となった以外はすべて宅地となっている。また、学 校や郵便局などの公用地は、江戸期に武家地あるいは寺地である。最 後に、農地は大幅に減少して宅地となっているが、街路の道筋の変化 はほとんどなく江戸期の地勢が保たれている。

\section{4. まとめ}

以上、文京区駒込地区の町地の成立と性質および变遷について検討 した結果、得られた知見を以下にまとめる。

・本稿で対象とした 27 ケ町 1566 軒のうち、麟祥院と伝通院の寺領町 屋 (門前以外) は 14 ケ町 697 軒ある。これらは何れも麟祥院領百 姓地、伝通院領百姓地が町化した町並地である。さらに門前町屋 のなかに、小間附町鑑で麟祥院領と記載される町が 3 ケ町 (43 軒) あり、これを含むと両寺院領の町地は 17 ヶ町 740 軒となり全体の 半数弱にものぼる。従って江戸期のこの地区の町地は、門前にお いても麟祥院および伝通院との経済的つながりが大変深かった事 がわかる。

・門前町屋は 9 ケ町 197 軒あり、いずれも駒込百姓地が町化したもの である。このうち 8 ケ町については寺院の移転に伴って引地や替 地したものであり、当地区の寺地の成立にも関連する。

・公課が公役銀と明記される町地は僅か 3 ケ町 371 軒であり全体の $1 / 4$ に満たない。その他の町地の公課はおおむ敉年貢と判断される。 これにより、ほとんどが百姓地が町化した町奉行十代官両支配の
町地であることが確認できる。

・本地区の名主支配は、麟祥院領町方が内海甚右衛門、伝通院領町方 が今井五郎兵衛に明確に分かれる。拝領町屋と門前町屋（麟祥院 領以外）については、谷中通りを挟んで南側を山下八左衛門、北 側を六兵衛が支配している。つまり、たとえ隣り合った町でも領 主が違えば支配する名主が異なる。

・明治 6 年沽券図では、江戸期の麟祥院領・伝通院領町屋の多くが無 記名となっている。これは当時徳川家菩提寺の境内地の多くが上 地された事と関連する。

・大正元年地籍図によれば、江戸期の町地で沽券図では無記名であっ た箇所は全て宅地となり、学校や郵便局などの公用地となった箇所 は、江戸期には武家地あるいは寺地である。このことは、一旦町化 した土地はその後公共に供されることは少なく、私有地（宅地）と なることを示している。江戸期の武家地・御用地で沽券図では無記 名だった箇所についても、公立病院（都立駒込病院）となった敷地 以外はすべて宅地となっている。

*本研究は、文部科学省科学研究費補助金・基盤研究 (C) (課題番号 21560670）の助成を受けて行なった研究の一部である。

\section{参考文献}

1）渡邊美樹：台東区谷中地区の寺地の変遷，日本建築学会計画系論文集 第 76 巻 第 669 号, pp. 2255-2262, 2011. 11

2) 渡邊美樹 : 台東区西浅草の寺町の変遷, 日本建築学会計画系論文集 第 78 巻 第 685 号, pp. 715-723, 2013.3

3）渡邊美樹: 文京区駒込地区の寺地の変遷, 日本建築学会計画系論文集 第 79 巻 第 697 号, pp. 837-844, 2014. 3

4) 渡邊美樹 : 江戸町人地の寺領について, 日本建築学会大会学術講演梗概集, 歴 史意匠, pp. 137-138，2014

5) 岩淵令治 : 江戸武家地の研究, 塙書房, 2004. 11

6) 吉原健一郎 : 初期江戸の土地問題, 江戸東京学への招待 2, NHK ブックス 19, pp. 92-111, 1995

7）都史紀要 34 江戸住宅事情，東京都公文書館，1990

8）吉田伸之：巨大城下町江戸の分節構造，山川出版社，1999

9) 藤川昌樹：近代武家集団と都市・建築，中央公論美術出版, 2002.2

10）松山恵：近代東京における広場の行方, 江戸の広場, pp. 63-86, 2005.7

11) 加藤仁美: 大名屋敷跡地の住宅地形成, 江戸東京学への招待 2, NHK ブックス, pp. $112-134,1995$

12）新編武蔵風土記稿 巻之十九, 大日本地誌体系第 1 巻, 雄山閣, pp. 356361,1977

13）麟祥院文書，豊島区史資料編 2, 豊島区，pp. 810-915，1981

14）文京区史巻 2, 文京区役所, 1968

15）駒込町方書上, 旧幕府引継書・町方書上三, 江戸東京博物館友の会, 2014.2

16）安永 3 小間附北方南方町鑑，東京都，1989

17）文京区たてもの応援団：東京都史跡駒込名主屋敷調査報告書, 2015

\section{参考地図 $\cdot$ 資料}

*1 吉原健一郎, 俵元昭（監修）：江戸 明治 東京重衩地図, APP カンパニー, 2004.4

$* 2$ 地籍地図・地籍台帳（東京）, 東京市区調查会，1989.3

*3 東京府地券課：沽券図, 東京都公文書館蔵, 1874

注

注 1）伝通院は、「浄土宗寿桂寺」と号し、応永 22（1415）年小石川に創建、慶 長 8 (1603) 年に徳川家康生母の方埋葬につき再興した。当時 830 石をも つ寺院であったとされる。

注 2) 麟祥院は寛永元 (1624) 年に開山、「報恩山 天澤寺」として湯島に創設し, 徳川家光の乳母春日局の法号により麟祥院と改号。臨済宗妙心寺派。

注 3)『小間附町鑑』の駒込片町の寺領の範囲は不明である。「町方書上」では「町 内全て年貢地」とあり、「駒込片町潮泉寺他八ヶ寺持添御年貢地鮫步書上」 
として、潮泉寺 5 畧 14 歩、正念寺 6 畧 8 歩、竜光寺 3 反 5 畧 8 歩、瑞泰寺 6 畧 25 歩、栄松院 4 畧 15 歩、清林寺 8 畧 12 歩、専西寺 1 反 5 畧 7 歩、顕 本寺 1 反 5 畧 16 歩、大林寺 9 反 7 畧 14 歩と記載されている。

注 4) 甚右衛門の苗字は『文京区史』に記載されている〔参考文献 14), p. 536) と共に、 「町方書上」に「駒込肴町外拾武ヶ所名主」として以下の記載がある。尾州野 間の内海より元亀年中（1570-1573）駒込村へ来る。寛永 6（1629）年に内海 彦右衛門より別家し、慶安 2（1649）年より名主を勤める。

注 5）天明 7 （1787）年 9 月 18 日付け、17 日に麟祥院領駒込村百姓勘右衛門の居 宅が焼失したことを報告する文書で「年寄 嘉平治」および「名主 甚右衛門」 の名が記載されている。また宽政元年 11 月 17 日付けで「年寄 嘉平次」、宝 暦 10 年 1 月 17 日付けで「畑主 嘉平治」、享和元年 11 月付けで「与頭 嘉 平次」、安政 3 年 12 月付けで「年寄 嘉平治」（いずれも名主は甚右衛門であ る）の名が記載された文書が記録されている〔参考文献 13)、p. 852-894】。

注 6）明治6（1873）年に地所には以下の 8 種の名称区別がなされた。

1. 皇居地 : 皇居および各所の離宮皇族の邸宅等

2. 神地 : 宗廟山陵および官国弊社府県社のある所

3. 官庁地：官省使察司府県の本庁及び支庁、裁判所。陸海軍の本営、分営

4. 官用地 : 官省使察司府県一時の用に供する地

5. 官有地 : 各所の公園地山林野沢湖沼の類

6. 公有地 : 野方秝物の類一般公有の税地又は無税地

7. 私有地：人民所有の田畑屋敷其他各種の土地

8. 除税地：埋葬地・制札場・行刑場・道路など

注 7)「明治 6 年沽券図」には、地所の境界と地券 (権) 者名、坪数が記されている。 重社地図および活券図の図上の大きさと表記の坪数とは相対的に異なる箇 所が多数あるが、本稿では坪数の表記に従った。 


\title{
ESTABLISHMENT AND TRANSFORMATION OF TOWNSPEOPLE'S LAND IN KOMAGOME DISTRICT, BUNKYO
}

\author{
Miki WATANABE* \\ * Assoc. Prof., Dept of Architecture, Ashikaga Institute of Technology, Dr. Eng.
}

This study employs historical maps and data to examine the establishment and transformation of the townspeople's land (Cyo-nin-chi) in Komagome district. Few townspeople's areas appeared before the Edo Period. In the early Edo Period, some farmlands were requisitioned as infantry residential land (Kumi-yashiki) or other feudal government land. Furthermore, many temples were relocated along with commercial towns in the Edo Period. Eventually, the townspeople's land in this area began to expand.

Many townspeople's lands were authorized as Machi-kata in 1737 and controlled by a town magistrate or Machi-Bugyo in 1745. This analysis found that the townspeople's lands in this area were organized into five categories as follows:

I. Hairyo-machi-ya: Bestowed townspeople's land

II. Townspeople's land of Rinsyo-in's territory

III. Townspeople's land of Dentu-in's territory

IV. Hyakusyo-machi-ya: Townspeople's land inclusive of other temple's territory

V. Monzen: Commercial town in front of the temple

Category I comprised three towns and 371 houses; the townspeople in these settlements paid via public labor or tax. Categories II and III together comprised 14 towns and 697 houses; the townspeople in these settlements paid an annual tribute to Rinsyo-in and Dentsu-in. Category IV comprised one town and 301 houses; the townspeople in these settlements paid an annual tribute (Nengu) to the Daikan of this area. Category V included nine towns and 197 houses; this category comprises commercial towns in front of temples, and the townspeople in these settlements might have paid an annual tribute (Nengu). Conversely, Rinsyo-in's territory, i.e., category II, was controlled by Jinemon Utsumi, who is the head of the village (Nanushi). Dentsu-in's territory, i.e., category III, was controlled by Gorobe Imai. Category IV was controlled by Hachizaemon Yamashita and Rokube. Category V comprised three towns that were occupied by Rinsyo-in's territories and were controlled by Jinemon Utsumi; the other towns were controlled by Hachizaemon Yamashita and Rokube. Thus, the town's establishment processes and the type of tax or dominion of the townspeople's lands were closely related. Furthermore, the townspeople's lands of Rinsyo-in and Dentsu-in's territories comprised 17 towns and 740 houses, which is approximately half of all townspeople's land. A characteristic of the outer part of Edo was that more than half of the townspeople's lands required an annual tribute as land tax (Nengu); however, less than one-third of the total houses were involved in public labor or paid tax.

After land requisition during the early Meiji Period, most of the townspeople's lands dominated by Rinsyo-in and Dentsu-in had no owner's name recorded, probably because these lands were returned to the original landowners. Almost all the Samurai lands, townspeople's lands that required public national taxes or labor were subdivided into small estates, and citizens immediately assumed ownership. 